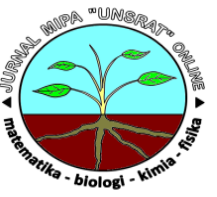

\title{
Analisis Beberapa Asam Organik dengan Metode High Performance Liquid Chromatography (HPLC) Grace Smart $\operatorname{Rp} 185 \mu$
}

\author{
Lungguk Sitorus a, Julius Pontoh a*, Vanda Kamu a \\ aJurusan Kimia, FMIPA, Unsrat, Manado
}

KATA K UNCI

asam organic

fase terbalik

HPLC

\begin{abstract}
A B S TR A K
Metode HPLC fase terbalik dengan kolom Grace Smart RP $185 \mu$ dapat digunakan untuk memisahkan dan menentukan konsentrasi asam-asam organik. Metode ini diaplikasikan suhu kolom $40{ }^{\circ} \mathrm{C}$ dan dideteksi pada panjang gelombang $210 \mathrm{~nm}$ dengan kalium dihidrogenfosfat $(\mathrm{pH} \mathrm{2,8)}$ sebagai fase gerak. Metode ini telah digunakan untuk menentukan asamasam organik seperti asam malat, asam askorbat, asam laktat, asam asetat, asam sitrat, asam piroglutamat, dan asam fumarat.
\end{abstract}

K E Y W O R D S

organic acid

reverse phase

HPLC
A B S T R A C T

Reverse phase HPLC method using Grace smart RP $185 \mu$ can used to separating and calculating concentration of organic acid. This method did on $40{ }^{\circ} \mathrm{C}$ column temperature and detected on wavelength $210 \mathrm{~nm}$ with potassium dihydrogen phosphate $(\mathrm{pH} 2.8)$ as mobile phase. Determining of organic acids such as malic acid, ascorbic acid, lactic acid, acetic acid, citric acid, pyroglutamic acid and fumaric acid.

\section{Pendahuluan}

Asam organik adalah senyawa organik yang memiliki gugus karboksil (Theron dan Lues, 2010). Asam organik dapat diklasifikasikan berdasarkan tipe rantai karbon (Alifatik, Alisiklik, Aromatik, atau heterosiklik), kejenuhan, subsitusi, dan nomor gugus fungsinya (Gomis,2000). Keasaman dari suatu senyawa organik ditentukan oleh nilai pKa dari senyawa tersebut. Semakin kecil nilai pKa dalam senyawa organik, sehingga semakin tinggi tingkat keasamannya.

Asam organik banyak digunakan dalam industri makanan, industri kimia dan industri farmasi. Asam organik digunakan sebagai bahan pengasaman, bahan aditif antimikroba, pengembang rasa dalam bir dan wiski (Gomis, 2000), juga sebagai bahan pengawet (Theron dan Lues, 2010). Sejumlah kecil asam organik terdapat dalam tanaman sebagai senyawa antara dalam metabolisme (Haard dan Chism, 1996). Beberapa contoh asam organik yang ditemukan dalam makanan adalah asam malat, asam laktat, asam fumarat, asam piroglutamat (Itoh et al., 1982), asam oksalat (Ergonul dan Nergiz, 2010), asam askorbat, asam sitrat dan asam tartrat (Nour et al., 2010).

Analisis asam-asam organik dapat dilakukan dengan cara titrasi, akan tetapi cara titrasi hanya bisa menentukan total asam organik sedangkan dalam buah-buahan terdapat banyak asam-asam organik. Metode analisis lain yang lebih baik untuk analisis asam organik adalah dengan menggunakan kromatografi.

Kromatografi adalah metode analisis yang menggunakan 2 fase (fase diam dan fase gerak) untuk memisahkan serangkaian senyawa kimia. Teknik ini dapat dilakukan dengan kromatografi lapis tipis, kromatografi cair dan kromatografi gas. Kelebihan analisis dengan kromatografi dibanding dengan titrasi adalah jumlah sampel yang dibutuhkan lebih sedikit dan dapat menganalisis berbagai jenis asam organik.

HPLC (High Performance Liquid Chromatography) adalah metode analisis yang

*Corresponding author: Jurusan Kimia FMIPA UNSRAT, Jl. Kampus Unsrat, Manado, Indonesia 95115; Email address: pontohjulius@yahoo.co.id Published by FMIPA UNSRAT (2015) 
banyak dilaporkan untuk analisis asam organik. Teknik HPLC dibedakan atas fase normal (menggunakan pelarut nonpolar sebagai fase gerak), fase terbalik (menggunakan pelarut polar sebagai fase gerak) dan penukar ion (menggunakan gradien konsentrasi ion dalam fase geraknya). Analisis asam organik dalam buah-buahan telah dilaporkan oleh Nour et al., (2010) menggunakan HPLC fase terbalik dengan kolom $\mathrm{C} 18$ sebagai fase diam dengan larutan fosfat $50 \mathrm{mM}$ sebagai fase gerak, juga telah dilaporkan oleh Ergonul dan Nergiz (2010) analisis buah zaitun dengan kolom penukar ion dan asam fosfat $0.1 \%(\mathrm{w} / \mathrm{v})$ sebagai fase gerak dan Itoh et al., (1982) melaporkan analisis asam organik pada nira aren menggunakan kromatografi penukar ion dengan asam fosfat $0.05 \%$ sebagai fase gerak. Namun demikian, Itoh et al., (1982) melakukan persiapan sampel yang lebih kompleks dengan mengekstraksi nira menggunakan metode soxlet.

Pada saat ini Fakultas Matematika dan IImu Pengetahuan Alam Universitas Sam Ratulangi telah memiliki HPLC dengan kolom Grace smart RP $185 \mu$ dengan detektor UV-VIS, namun belum diketahui apakah peralatan ini dapat digunakan untuk analisis asam organik pada buah duku dan langsat. Penelitian ini akan dilakukan untuk mengembangkan kolom Grace smart RP $185 \mu$..

\section{Material dan Metode}

Peralatan yang digunakan dalam penelitian ini adalah HPLC Cecil CE4201, uv detector SPD- 20A, pompa LC- 20AD, oven kolom Grace smart RP $185 \mu$ (panjang kolom $15 \mathrm{~cm}$ dan diameter 4,6 mm), pHmeter, blender, alat-alat gelas secara umum pyrex, schott Duran, pipet, mikro pipet, aluminium foil, botol serum, labu ukur $100 \mathrm{~mL}$ dan $1000 \mathrm{~mL}$. Bahan yang digunakan adalah Kalium dihydrogen fosfat, aquades, asam asetat $10 \%$, asam sitrat, asam malat, asam laktat $10 \%$, asam piroglutamat, asam fumarat, saringan Whatman $0.2 \mu \mathrm{m}$, dan Whatman $0.45 \mu \mathrm{m}$.

\subsection{Pembuatan Kurva Standar Asam Organik}

\subsubsection{Asam Malat}

Disiapkan larutan stok asam Malat konsentrasi 2\% (dengan melarutkan asam Malat sebanyak $2 \mathrm{~g}$ dalam $100 \mathrm{~mL}$ buffer fosfat). Selanjutnya disiapkan 4 botol vial, masing- masing diisi dengan asam stok sebanyak $0.2 \mathrm{~mL}, 0.5 \mathrm{~mL}, 1 \mathrm{~mL}$ dan $2 \mathrm{~mL}$, selanjutnya ditambahkan dengandengan larutan fosfat hingga $5 \mathrm{~mL}$ dan disimpan pada suhu $\pm 4^{\circ} \mathrm{C}$ selama proses penelitian. Dari kosentrasi asam organik standar, dibuat kurva standar (Luas area vs konsentrasi).

\subsubsection{Asam Laktat}

Disiapakan larutan stok asam Laktat konsentrasi $1 \%$ yaitu dengan menambahkan $1 \mathrm{~mL}$ asam Laktat kedalam $90 \mathrm{~mL}$ buffer fosfat kemudian ditambahkan larutan buffer sampai $100 \mathrm{~mL}$, selanjutnya disiapkan 3 buah botol vial, masing- masing diisi dengan asam stok sebanyak0.2 mL, 0.5 $\mathrm{mL}, 1 \mathrm{~mL}$ dan $2 \mathrm{~mL}$, selanjutnya ditambahkan dengan larutan fosfat hingga $5 \mathrm{~mL}$ dan disimpan pada suhu $\pm 4^{\circ} \mathrm{C}$ selama proses penelitian. Dari kosentrasi asam organik standar, dibuat kurva standar (Luas area vs konsentrasi).

\subsubsection{Asam Asetat}

Disiapkan larutan stok asam Asetat konsentrasi $1 \%$ yaitu dengan menambahkan $1 \mathrm{~mL}$ asam Asetat kedalam $90 \mathrm{~mL}$ buffer fosfat kemudian ditambahkan larutan buffer sampai $100 \mathrm{~mL}$, selanjutnya disiapkan 3 buah botol vial, masingmasing diisi dengan asam stok sebanyak $0.2 \mathrm{~mL}$, $0.5 \mathrm{~mL}, 1 \mathrm{~mL}$ dan $2 \mathrm{~mL}$, selanjutnya ditambahkan dengan larutan fosfat hingga $5 \mathrm{~mL}$ dan disimpan pada suhu $\pm 4{ }^{\circ} \mathrm{C}$ selama proses penelitian. Dari kosentrasi asam organik standar, dibuat kurva standar (Luas area vs konsentrasi).

\subsubsection{Asam Sitrat}

Disiapkan larutan stok asam Sitrat konsentrasi 0.1\% (dengan melarutkan asam Sitrat sebanyak 0.1 $\mathrm{g}$ dalam $100 \mathrm{~mL}$ buffer fosfat). Selanjutnya disiapkan 4 buah botol vial, masing-masing diisi dengan asam stok sebanyak $0.2 \mathrm{~mL}, 0.5 \mathrm{~mL}, 1 \mathrm{~mL}$ dan $2 \mathrm{~mL}$, selanjutnya ditambahkan dengan larutan fosfat hingga $5 \mathrm{~mL}$ dan disimpan pada suhu $\pm 4{ }^{\circ} \mathrm{C}$ selama proses penelitian. Dari kosentrasi asam organik standar, dibuat kurva standar (Luas area vs konsentrasi).

\subsubsection{Asam Piroglutamat}

Disiapkan larutan stok asam Piroglutamat konsentrasi $0.1 \%$ (dengan melarutkan asam Piroglutamat sebanyak $0.1 \mathrm{~g}$ dalam $100 \mathrm{~mL}$ buffer fosfat). Selanjutnya disiapkan 4 buah botol vial, masing-masing diisi dengan asam stok sebanyak $0.2 \mathrm{~mL}, 0.5 \mathrm{~mL}, 1 \mathrm{~mL}$ dan $2 \mathrm{~mL}$, selanjutnya ditambahkan dengan larutan fosfat hingga $5 \mathrm{~mL}$ dan disimpan pada suhu $\pm 4{ }^{\circ} \mathrm{C}$ selama proses penelitian. Dari kosentrasi asam organik standar, dibuat kurva standar (Luas area vs konsentrasi).

\subsubsection{Asam Fumarat}

Disiapkan larutan stok asam Fumarat konsentrasi $0.1 \%$ (dengan melarutkan asam Fumarat sebanyak $0.1 \mathrm{~g}$ dalam $100 \mathrm{~mL}$ buffer fosfat). Selanjutnya disiapkan 4 buah botol vial, masing-masing diisi dengan asam stok sebanyak $0.2 \mathrm{~mL}, 0.5 \mathrm{~mL}, 1 \mathrm{~mL}$ dan $2 \mathrm{~mL}$, selanjutnya ditambahkan dengan larutan fosfat hingga $5 \mathrm{~mL}$ dan disimpan pada suhu $\pm 4{ }^{\circ} \mathrm{C}$ selama proses penelitian. Dari kosentrasi asam organik standar, dibuat kurva standar (Luas area vs konsentrasi).

\subsubsection{Asam Askorbat}

Disiapkan larutan stok asam Askorbat konsentrasi $0.4 \%$ (dengan melarutkan vitamin C sebanyak $0.4 \mathrm{~g}$ dalam $100 \mathrm{~mL}$ buffer fosfat). Selanjutnya disiapkan 4 buah botol vial, masingmasing diisi dengan asam stok sebanyak $0.2 \mathrm{~mL}$, $0.5 \mathrm{~mL}, 1 \mathrm{~mL}$ dan $2.66 \mathrm{~mL}$, selanjutnya ditambahkan dengan larutan fosfat hingga $4 \mathrm{~mL}$ dan disimpan pada suhu $\pm 4^{\circ} \mathrm{C}$ selama proses 
penelitian. Dari kosentrasi asam organik standar, dibuat kurva standar (Luas area vs konsentrasi).

\subsection{Analisis HPLC (Nour et al., 2010)}

Standar asam organik buah duku dan langsat yang akan digunakan dalam penelitian ini dianalisis dengan kromatografi fasa terbalik menggunakan kolom Grace smart RP $185 \mu$, dan dibaca pada $\lambda=$ $210 \mathrm{~nm}$. Sebelum diinjeksi kedalam HPLC, standar asam organik dan sampel disaring terlebih dahulu dengan kertas whatman $0.2 \mu \mathrm{m}$.

Analisis dilakukan pada kondisi isokratik pada suhu $40{ }^{\circ} \mathrm{C}$ dengan menggunakan larutan fosfat $50 \mathrm{mM}$ sebagai fasa gerak (melarutkan $6.8 \mathrm{~g}$ kalium dihidrogen fosfat dalam $900 \mathrm{~mL}$ air, nilai $\mathrm{pH}$ diatur dengan menambahkan asam fosfat sampai 2.8 menggunakan $\mathrm{pH}$ meter, lalu ditambahkan dengan air hingga $1000 \mathrm{~mL}$ ), selanjutnya disaring dengan kertas whatman $0.45 \mu \mathrm{m}$. laju alir fasa gerak diatur $0.7 \mathrm{~mL} /$ menit.Sebelum dilakukan injeksi, alat harus distabilkan terlebih dahulu.

\section{Hasil dan Pembahasan}

\subsection{Kurva Standar Asam Organik}

Kurva standar asam malat ditampilkan pada Gambar 1. Standar asam malat ini dibuat dengan variasi konsentrasi $0.2 \%, 0.4 \%, 1 \%$ dan $2 \%$ yang diplotkan dengan luas area dari masing-masing konsentrasi dan menghasilkan kurva yang tidak cukup linear dengan koefesien korelasi sebesar 0.986 dengan nilai respons sebesar $8271 \mathrm{~mA}$ persent asam malat.

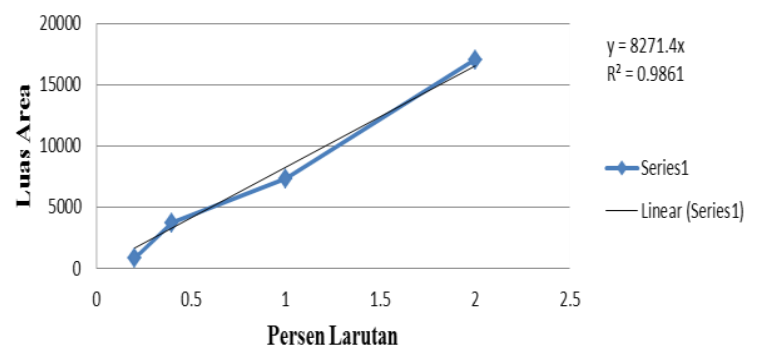

Gambar 1. Kurva standar asam malat

Gambar 2 menampilkan kurva standar untuk asam askorbat. Variasi konsentrasi asam standar untuk asam askorbat dimulai dengan konsentrasi 0,016\% 0,04\% 0,08\% dan 0.16\%.

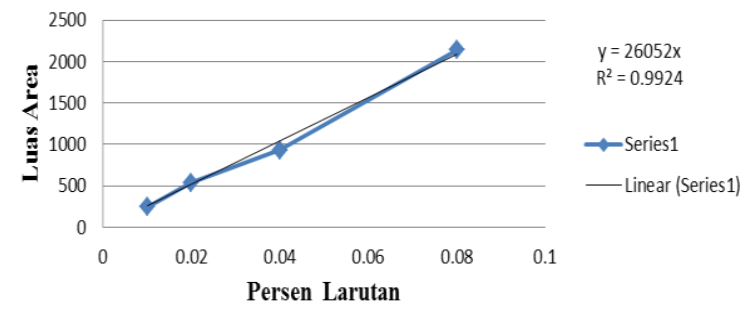

Gambar 2. Kurva standar asam askorbat
Penggunaan konsentrasi variasi tersebut disesuaikan dengan luas area dari asam organik dalam sampel untuk mempermudah dalam perhitungan konsentrasi asam organik dalam sampel. Koefisien korelasi untuk asam askorbat sebesar 0,992.

Linearitas kurva standar asam laktat dapat dilihat pada Gambar 3 dan koefisien korelasi sebesar 0,966 dan merupakan kurva yang kurang linear. Standar asam laktat yang digunakan pada penelitian ini berbentuk cairan sehingga variasi konsentrasi dari asam laktat dinyatakan dalam v/v. Adapun variasi konsentrasi untuk asam laktat dibuat dengan mengambil $0.004 \%, 0.01 \%, 0.02 \%$ dan $0.04 \%$.

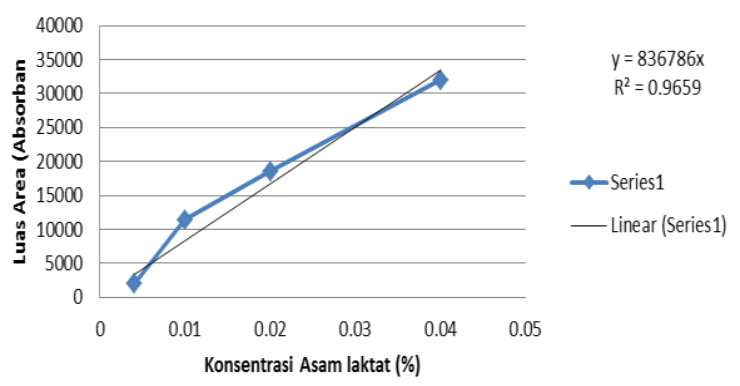

Gambar 3. Kurva standar asam laktat

Pada gambar 4 ditampilkan kurva standar dari asam sitrat dengan koefisien korelasi sebesar 0.997 yang menunjukkan linearitas yang baik. Variasi konsentrasi asam sitrat dimulai dengan $0.004 \%, 0.01 \%, 0.02 \%$ dan 0.04\%.

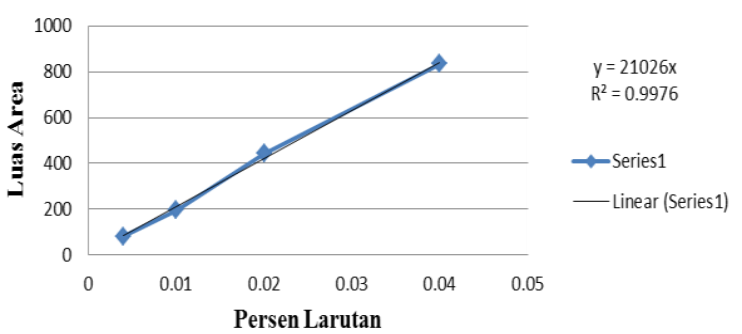

Gambar 4. Kurva standar asam sitrat

Pada gambar kurva standar asam asetat diperoleh linearitas yang cukup baik (Gambar 5) sebesar 0,998. Variasi konsentrasi pada asam asetat sama halnya dengan konsentrasi pada asam laktat yaitu $0.004 \%, 0.01 \%$, 0.02\% dan 0.04\%.

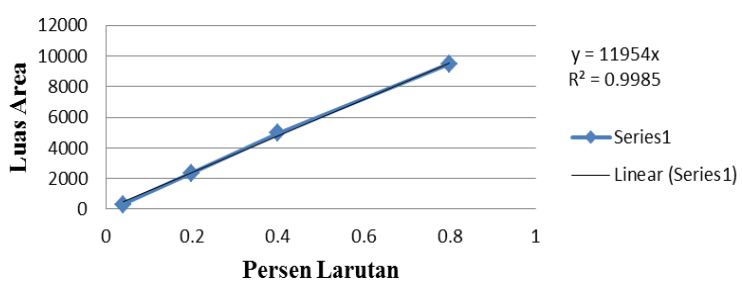

Gambar 5. Kurva standar asam asetat

Ditinjau dari variasi konsentrasi dan luas area dari beberapa asam organik standar yaitu asam asetat, asam laktat dan asam malat, ketiganya 
memiliki tingkat sensifitas yang hampir sama. Tingkat sensitifitas dapat dilihat dari seberapa besar luas area dan tinggi puncak yang diperoleh dari konsentrasi tertentu. Sensitifitas yang tinggi jika menghasilkan luas area dan puncak yang besar, padahal konsentrasi yang digunakan adalah kecil. Sedangkan sensifitas yang rendah jika luas area dan puncak yang diperoleh pada kromatogram adalah kecil sedangkan konsentrasi yang digunakan besar.

Gambar 6 menunjukkan kurva standar asam piroglutamat yang memberikan koefisien korelasi sebesar 0.993. Variasi konsentrasi untuk asam piroglutamat adalah $0.004 \%, 0.01 \%, 0.02 \%$ dan $0.04 \%$, meskipun linearitas yang di berikan cukup baik akan tetapi nilai korelasi yang di berikan tidak terlalu cukup baik. Hal ini disebabkan pembacaan luas area yang cukup tinggi pada konsentrasi $0.04 \%$, dimana asam piroglutamat merupakan asam organik yang memiliki sensitivitas yang tinggi.

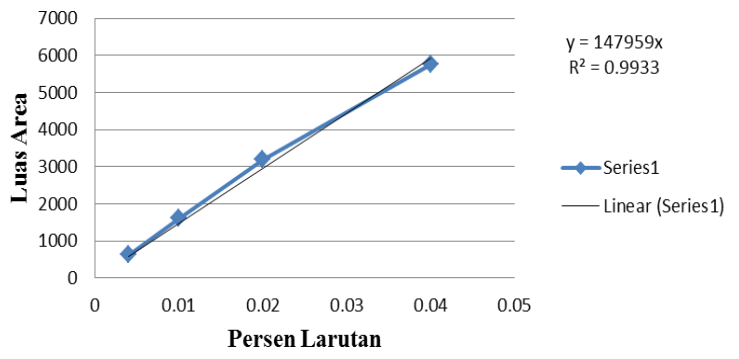

Gambar 6. Kurva standar asam piroglutamat

Asam fumarat adalah asam standar yang dibuat dengan konsentrasi yang paling rendah di bandingkan asam standar lainnya, yaitu dimulai dengan konsentrasi $0.0004 \%$ karena pada konsentrasi tersebut sudah menghasilkan puncak dengan luas area sebesar 983.4, variasi konsentrasi selanjutnya adalah $0.0008 \%, 0.0016 \%$ dan $0.008 \%$. Pada Gambar 7 kurva standar yang diberikan kurang cukup baik yaitu koefisien korelasi sebesar 0.992. Konsentrasi asam fumurat dinyatakan dalam g. $\mathrm{mL}^{-1}$ sama halnya dengan asam malat, asam askorbat, asam sitrat dan asam piroglutamat karena asam-asam standar tersebut berbentuk bubuk yang selanjutnya diencerkan dengan buffer fosfat untuk pembuatan variasi konsentrasi.

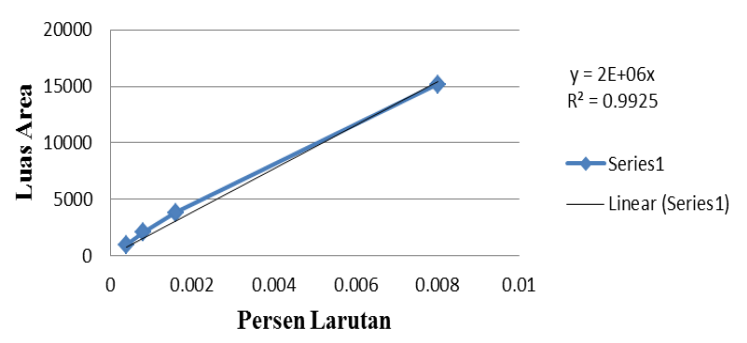

Gambar 7. Kurva standar asam fumarat

\subsection{Respon Asam-asam Organik}

Untuk menentukan keberadaan beberapa senyawa organik dalam sampel buah duku dan langsat, dibutuhkan standar dari asam-asam organik. Asam-asam organik standar ini dianalisis dengan HPLC menggunakan kolom Grace smart RP $185 \mu$ dengan laju alir $0.7 \mathrm{~mL} /$ menit serta suhu kolom Grace smart RP $185 \mu 40{ }^{\circ} \mathrm{C}$ dan panjang gelombang $210 \mathrm{~nm}$.

Tabel 1. Volume larutan asam-asam standar yang dianalisis dengan HPLC

\begin{tabular}{ccc}
\hline Asam Organik & $\begin{array}{c}\text { Volume } \\
\text { Larutan } \\
(\mathrm{mL})\end{array}$ & $\begin{array}{c}\text { Persen } \\
\text { Larutan } \\
(\%)\end{array}$ \\
\hline Asam Malat & 1 & 0.4 \\
\hline Asam Askorbat & 1 & 0.04 \\
\hline Asam Laktat & 1 & 0.04 \\
\hline Asam Asetat & 1 & 0.4 \\
\hline Asam Sitrat & 1 & 0.1 \\
\hline Asam Piroglutamat & 1 & 0.01 \\
\hline Asam Fumarat & 1 & 0.0016 \\
\hline
\end{tabular}

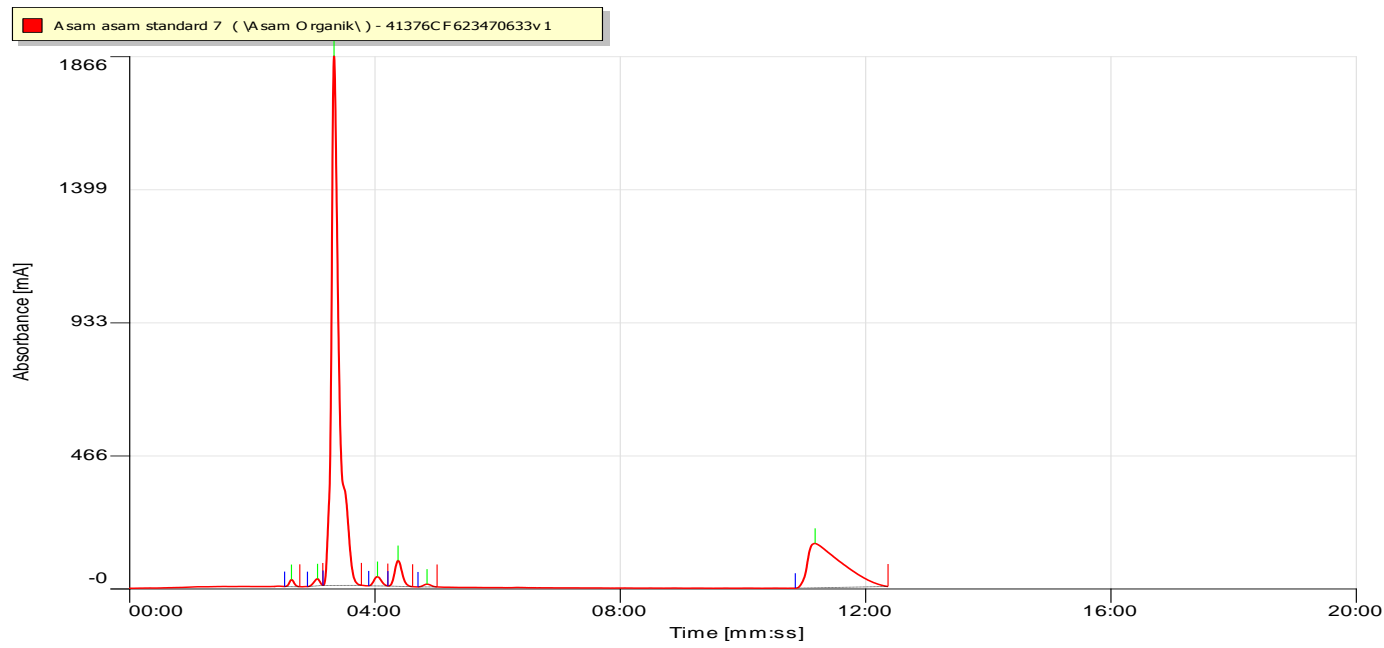

Gambar 8. Kromatogram asam-asam standar 
Waktu retensi $\left(t_{r}\right)$ dari campuran asam-asam organik standar ditampilkan pada Tabel 2 . Kromatogram (Gambar 8) dari campuran asamasam organik inilah yang digunakan untuk analisis beberapa senyawa organik dalam ekstrak buah duku dan langsat yang dilihat berdasarkan perbedaan waktu retensinya $\left(t_{r}\right)$. Campuran asamasam organik standar ini dibuat dengan mencampurkan masing-masing $1 \mathrm{~mL}$ dari semua asam-asam standar yang telah di analisis dengan HPLC Grace smart RP $185 \mu$ dengan persen larutan yang berbeda (Tabel 1).

Tabel 2. Waktu retensi asam-asam organik yang dianalisis dengan HPLC

\begin{tabular}{ccc}
\hline Asam Organik & $\begin{array}{c}\lambda \\
(\mathrm{nm})\end{array}$ & $\begin{array}{c}\mathrm{t}_{\mathbf{r}} \\
\text { (Menit) }\end{array}$ \\
\hline Asam Malat & 210 & 2.41 \\
\hline Asam Askorbat & 210 & 3.08 \\
\hline Asam Laktat & 210 & 3.20 \\
\hline Asam Asetat & 210 & 3.27 \\
\hline Asam Sitrat & 210 & 4.08 \\
\hline Asam Piriglutamat & 210 & 4.27 \\
\hline Asam Fumarat & 210 & 4.56
\end{tabular}

Waktu retensi dari asam laktat hasil penelitian ini berbeda dengan waktu retensi asam laktat yang ditampilkan oleh hasil penelitian Limo (2015) yang menggunakan analisis kromatografi dengan kolom YMC Triat $\mathrm{C}_{18}$, yaitu asam laktat memiliki $\mathrm{t}_{\mathrm{r}}=7.31$.

\section{Kesimpulan}

Berdasarkan tujuh asam organik yang digunakan (asam malat, asam askorbat, asam laktat, asam asetat, asam sitrat, asam piroglutamat dan asam fumarat), asam-asam organik yang terdeteksi menggunakan HPLC Cecil CE4201 dengan kolom Grace smart RP $185 \mu$. Terdapat beberapa puncak yang belum teridentifikasi apakah senyawa asam organik atau bukan sehingga metode ini masih perlu dioptimalkan.

\section{Daftar Pustaka}

Ardianingsih, R. 2009. Penggunaan High Performance Liquid Chromatography (HLPC) dalam Proses Analisa Deteksi Ion. Berita Dirgantara.10: 101-104

Day R. A.Jr., and Underwood A.L.2001. Analisis Kimia Kuantitatif. Erlangga. Jakarta

Fessenden, R. J., and J. S. Fessenden.1986. Kimia Organik. Edisi ke-3.Erlangga. Jakarta

Gomis, D. B. 2000. HPLC analysis of organic acids. Di dalam : Nollet, L. M. L. (ed). Food Analysis by HPLC. CRC Press, New York

Haard, N. F., and G. W. Chism. 1996. Characteristic Of Edible Plant Tissues. Di dalam: Fennema, 0. R. Food Chemistry. CRC Press, New York

Itoh, T., C. H. Widjaja, A. Matsuyama, M. Z. Nasution, and J. Kumendong. 1982. Compositional Characteristics of Nira-Palm Juice of High Sugar Content From Palm Tree. Di dalam: Agricultural Production and Processing Technology. Proceeding of IPB-JICA International Synposium, Bogor. HIm 233-240

Nour, V., I. Trandafir, and M. E. Ionica. 2010. HPLC Organic Acid Analysis In Different Citrus Juice Under Reversed Phase Condition. NotulaeBotanicae Horti Agrobotanici ClujNapoca.11: 42-48

Shepard, L. 2012. Relating Sensory and Chemical Properties to Consumer Acceptance of Sour Cream : Organic Acid [ thesis ]. Faculty of North Carolina State University, North Carolina

Theron, M. M., and J. F. R. Lues. 2010. Organic Acids and Food Preservation. CRC press, New York The Journey of Chemistry.2012.High Performance Liquid Chromatography (HPLC). [27 Februari 2012] 